\title{
Simulation and Testing of the Calorific Value and Cost Analysis of Biomass Pyrolysis for Heating, Cooling, and Power Production
}

\author{
Kaidi Zhang, ${ }^{a}$ Xunwang Shi, ${ }^{a}$ Xin Xin, ${ }^{a}$ Ken Chen, ${ }^{a}$ Jianfen Li, ${ }^{\text {a, } *}$ Weitao He, \\ Zhenhua Qin, ${ }^{\mathrm{a}}$ Haiping Yang, ${ }^{\mathrm{b}}$ and Chen Zhang ${ }^{\mathrm{c}}$
}

\begin{abstract}
$\mathrm{Ni}$-based catalysts supported on olivine were synthesized for cracking the biomass and producing the syngas. Syngas is used directly as fuel source for the cooling, heating, and power (CCHP) system, which can be produced through biomass pyrolysis process. Integrating combined CCHP systems with biomass pyrolysis results in a sustainable distributed energy system that effectively utilizes biomass resources and improves energy efficiency. To achieve a higher energy efficiency and more cost-effective operation, a simplified cost analysis method based on the Advanced System for Process Engineering (Aspen Plus) was applied to the CCHP system based on biomass pyrolysis. First, syngas was used as a fuel source for the CCHP system, which can be produced through a biomass pyrolysis experiment. In the experiment, the yields of the gas before and after the addition of a catalyst were compared. Second, syngas was passed to the reactor in Aspen Plus, which simulated the calorific values of the syngas produced by biomass pyrolysis under different conditions. Moreover, the simulated syngas heat values were applied to a TFRJ3K straw gas engine. Finally, the cost of the syngas for power generation, cooling, and heating was calculated. The power generation cost was 1.2 $\mathrm{RMB} / \mathrm{kW}$, the air conditioning refrigeration cost was $22.752 \mathrm{RMB} / \mathrm{d}$, and the household heating cost was $20 \mathrm{RMB} / \mathrm{d}$.
\end{abstract}

Keywords: Biomass; Pyrolysis; Syngas; CCHP; Cost analysis

Contact information: a: School of Chemical and Environmental Engineering, Wuhan Polytechnic

University, Wuhan 430023, P. R. China; b: State Key Laboratory of Coal Combustion, School of Power and Energy Engineering, Huazhong University of Science and Technology, 430074 Wuhan, P. R. China; c: Blooming (Beijing) Technology Company limited, 100012 Beijing, P. R. China;

*Corresponding author: lijfen@163.com

\section{INTRODUCTION}

Combined cooling, heating, and power (CCHP) systems that use natural gas as fuel are efficient and act as environmental energy distribution systems in buildings (Wang et al. 2014). The problem of energy shortages and environmental pollution has made the energy sector focus increasingly on issues concerning saving fossil fuels and renewable energy development (Wang et al. 2015b). Among energy resources, biomass is considered the fourth largest energy source, after oil, coal, and natural gas (Maraver et al. 2013; Wang et al. 2015b). Therefore, the development and utilization of biomass energy has become an important task (Mertzis et al. 2014).

Wang et al. (2016) studied the key parameters of the biomass gasification process, proposed suitable temperatures and oxygen equivalent ratios, and simulated the process with Aspen Plus. Wang et al. (2015a) studied the effective energy efficiency and effective 
energy destruction of the cooling, heating, and power system, product cost and cost allocation, and proposed a sensitivity analysis to determine the factors that affect the unit energy consumption cost of the product, such as the biomass and investment costs, interest rate, service life, and operating hours.

In this study, the effect of $\mathrm{Ce}$ and $\mathrm{La}$ promoter on the reaction activity were investigated, and the prepared catalysts were calcined at different temperatures. The experimental results showed that different catalysts and calcination temperatures will have a greater impact on the composition and content of biomass syngas. A simplified Aspen Plus model was proposed to introduce biomass syngas into this model and more intuitively observe the cost of biomass for refrigeration, heating, and power generation.

\section{EXPERIMENTAL}

\section{Materials}

The biomass used in the experiment was wheat straw collected from a farm in Hubei Province. The straw was dried in the natural conditions for a week to remove natural moisture. The materials used included natural olivine (Xixia Hongtai Olivine Co. Ltd., Xixia Henan, China), nickel nitrate (AR, Tianjin Damao Chemical Reagent Factory, Tianjin, China), sodium metavanadate (AR, Tianjin Beilian Fien Chemicals Development Co. Ltd., Tianjin, China), cerium nitrate hexahydrate (AR, Shanghai Macklin Biochemical Co. Ltd., Shanghai, China), lanthanum nitrate (AR, Shanghai Shanpu Chemical Co. Ltd., Shanghai, China), and urea (AR, Tianjin Kaitong Chemical Reagent Co. Ltd., Tianjin, China). The software used was Aspen Plus (AspenTech, Bedford, MA, USA).

\section{Methods}

\section{Biomass preparation}

The wheat straw was crushed, ground, and sieved to a particle size between 0.15 and $0.3 \mathrm{~mm}$. This particle size made it possible to provide the heat transfer required for the pyrolysis step. The treated wheat straw was placed in a sealed bag and stored under natural conditions for the further use.

\section{Preparation of the catalysts}

First, the olivine was crushed to a 20-mesh to 30-mesh size in a crusher (Atong et al. 2011). Second, a certain percentage of the olivine and nickel nitrate was placed in a $500-\mathrm{mL}$ three-necked flask. Next, $60 \mathrm{~g}$ of urea and $250 \mathrm{~mL}$ of deionized water were added to the 500-mL three-necked flask. The three-necked flask was placed in an oil bath and reacted at $115^{\circ} \mathrm{C}$ for $2 \mathrm{~h}$, and then stood for $2 \mathrm{~h}$. After evaporation of the excess water, the samples were dried overnight at $110{ }^{\circ} \mathrm{C}$ and calcined at $900{ }^{\circ} \mathrm{C}$ to $1100{ }^{\circ} \mathrm{C}$ for $2 \mathrm{~h}$ with a heating rate of $10^{\circ} \mathrm{C} / \mathrm{min}$ (Shi et al. 2018). Finally, six catalysts were synthesized, a) 900$\mathrm{Ni}-\mathrm{V}$, (b) 900-Ni-V-Ce, (c) 900-Ni-V-La, (d) 1100-Ni-V, (e) 1100-Ni-V-Ce, and (f) 1100$\mathrm{Ni}-\mathrm{V}$-La (Named according to the elemental composition of the catalyst using the symbol of the element in the period table).

\section{Evaluation of the Catalytic Activity}

The activity of the Ni/olivine catalyst was evaluated in a BTF-1200 fixed pyrolysis furnace (Anhui Beyik Equipment Technology Co. Ltd., Hefei Anhui, China) (Fig. 1). 
The wheat straw and catalytic bed with a catalyst, which was in a porcelain boat, was sent to the pyrolysis furnace through the flange mouth before the trial. The purpose of introducing nitrogen was to discharge the air that was in the fixed pyrolysis furnace. The bricks were insulated to maintain the temperature of the reactor. The reactor was pushed to where the biomass particles stayed and the cracking temperature was set (Shi et al. 2018). A Gasboard-3100 infrared gas analyzer (Hubei, Ruiyi Automatic Control System Co. Ltd., Wuhan Hebei, China) was used to analyze the gas composition and content. The exhaust gas was processed or burned.

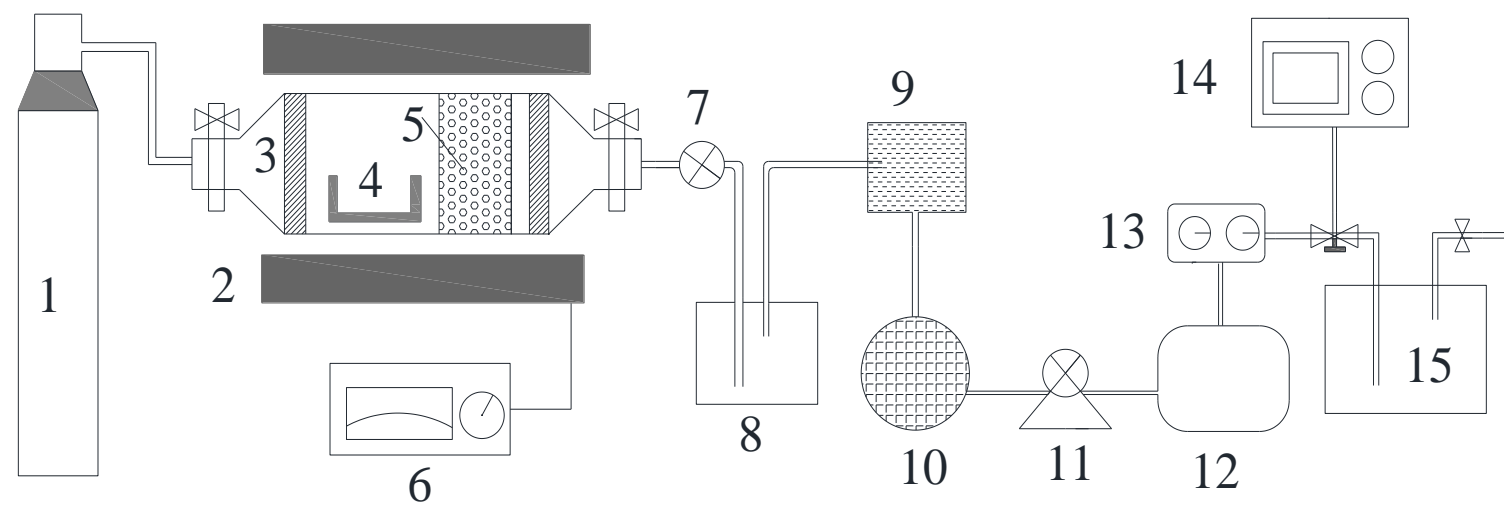

Fig. 1. Flow scheme of the bench scale reactor for catalytic pyrolysis of the straw biomass: (1) nitrogen; (2) pyrolysis gasifier and thermocouples; (3) insulation brick; (4) porcelain boat; (5) catalytic bed and catalyst; (6) temperature controller; (7) waterproof valve; (8) water channel; (9) particle filter; (10) gas dryer (silica gel); (11) pump; (12) gas buffer package; (13) flowmeter; (14) gas analyzer; and (15) fire prevention

\section{RESULTS AND DISCUSSION}

\section{Characterization of the Catalysts}

XRD analysis

X-ray diffraction was conducted to obtain structural information about the freshly synthesized olivine samples. Figure 2 shows the XRD patterns for the catalysts.

The XRD patterns of the Ni/V, Ni/V-Ce, and Ni/V-La catalysts are shown in Fig. 2 . In the case of the $900-\mathrm{Ni} / \mathrm{V}$ catalyst, the peaks at $43.419^{\circ}$ and $62.919^{\circ}$ were identified as $\mathrm{NiO}$ (PDF\#71-1179) (Quan et al. 2018).

In the case of the $900-\mathrm{Ni} / \mathrm{V}-\mathrm{Ce}$ catalyst, the peaks at $28.063^{\circ}, 32.379^{\circ}$, and $54.980^{\circ}$ were identified as $\mathrm{Ce}_{2} \mathrm{O}_{3}$ with the pattern PDF\#71-0567 (Mokhnachuk et al. 2007).

In the case of the $900-\mathrm{Ni} / \mathrm{V}$-La catalyst, the peaks at $29.899^{\circ}, 39.897^{\circ}$, and $52.420^{\circ}$ were identified as $\mathrm{La}_{2} \mathrm{O}_{3}$ with the pattern PDF\#73-2141 (Remiro et al. 2013; Valle et al. 2013). In the case of the $1100-\mathrm{Ni} / \mathrm{V}$ catalyst, the peaks at $36.560^{\circ}, 43.318^{\circ}, 62.860^{\circ}$, and $79.120^{\circ}$ were identified as $\mathrm{NiO}$ (PDF\#71-1179) (James et al. 2014; Quan et al. 2018).

In the case of the $1100-\mathrm{Ni} / \mathrm{V}-\mathrm{Ce}$ catalyst, the peaks at $27.840^{\circ}, 35.659^{\circ}$, and $67.121^{\circ}$ were identified as $\mathrm{Ce}_{2} \mathrm{O}_{3}$ with the pattern PDF\#74-1145 (Mokhnachuk et al. 2007).

In the case of the $1100-\mathrm{Ni} / \mathrm{V}-\mathrm{La}$ catalyst, the peaks at $26.177^{\circ}, 29.920^{\circ}$, and $62.039^{\circ}$ were identified as $\mathrm{La}_{2} \mathrm{O}_{3}$ with the pattern PDF\#73-2171 (Mazumder and de Lasa 2015). 

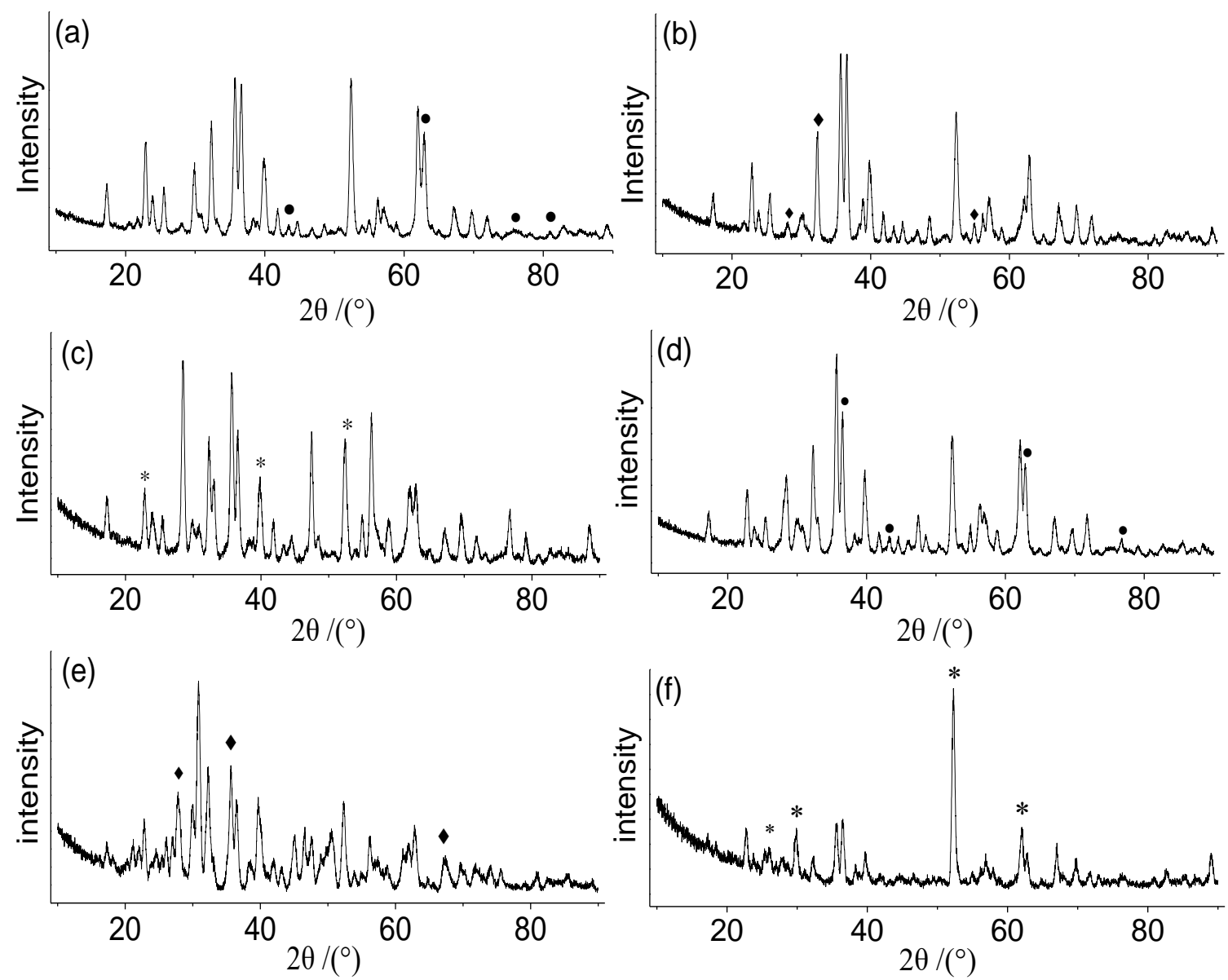

Fig. 2. XRD patterns of the catalysts: (a) 900-Ni-V, (b) 900-Ni-V-Ce, (c) 900-Ni-V-La, (d) 1100-Ni$\mathrm{V},(\mathrm{e}) 1100-\mathrm{Ni}-\mathrm{V}-\mathrm{Ce}$, and (f) $1100-\mathrm{Ni}-\mathrm{V}-\mathrm{La}$

\section{Influences of the Process Conditions}

Syngas yield of biomass

The influence of pyrolysis temperature of $600{ }^{\circ} \mathrm{C}$ on syngas component by the catalysts is shown in Fig. 3.

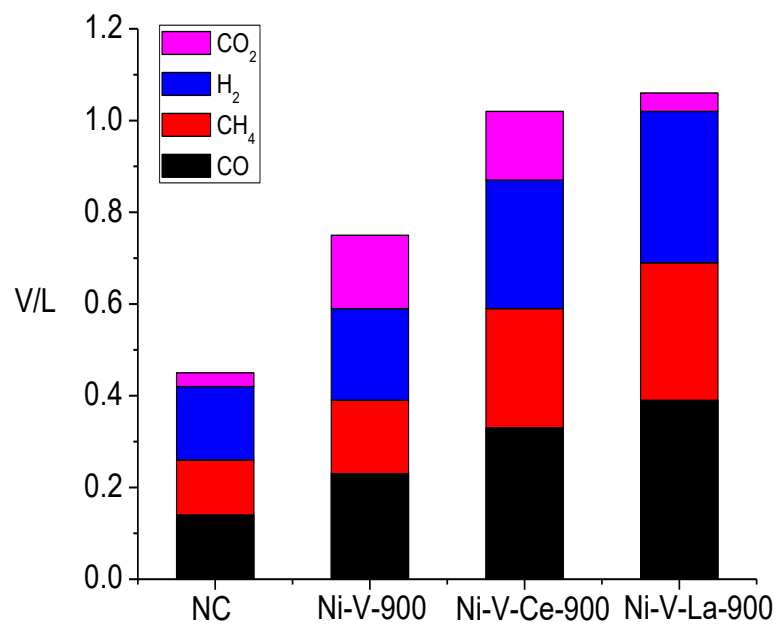

Fig. 3. Influence of calcination at $900^{\circ} \mathrm{C}$ with a pyrolysis temperature of $600^{\circ} \mathrm{C}$ 
The effects of pyrolysis temperature of $800{ }^{\circ} \mathrm{C}$ on syngas components by the catalysts are shown in Fig. 4.

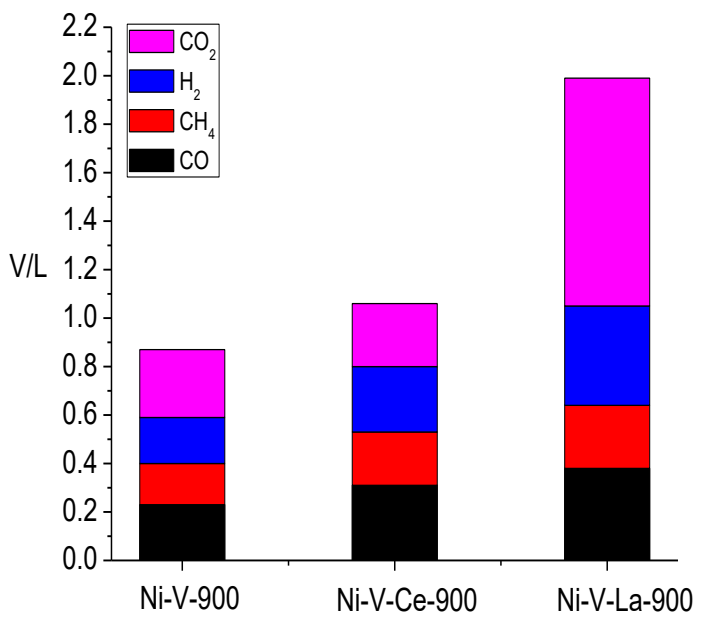

Fig. 4. Influence of calcination at $900{ }^{\circ} \mathrm{C}$ with a pyrolysis temperature of $800{ }^{\circ} \mathrm{C}$

The effects of calcination at $900{ }^{\circ} \mathrm{C}$ on syngas components by the catalysts are shown in Fig. 5.

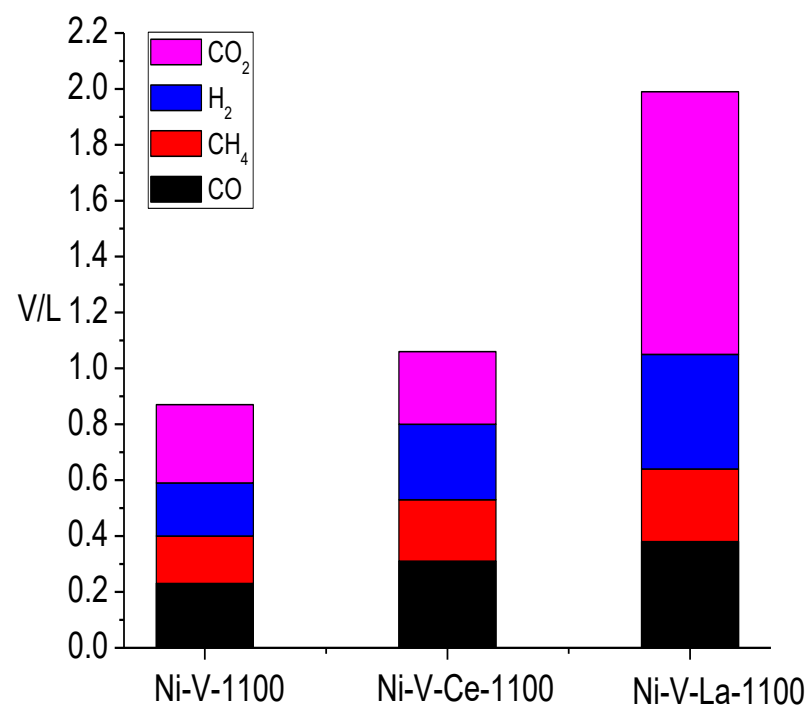

Fig. 5. Influence of calcination at $1100^{\circ} \mathrm{C}$ with a pyrolysis temperature of $600{ }^{\circ} \mathrm{C}$

The influence of calcination at $1100^{\circ} \mathrm{C}$ on syngas component by the catalysts is shown in Fig. 6.

\section{Effect of the calcination temperature}

Figures 3 through 6 compare the gas production of the experimentally determined syngas catalyzed at different calcination temperatures. The syngas yield after adding the catalyst was higher than that with no catalyst (Cheah et al. 2013). The carbon monoxide $(\mathrm{CO})$, methane $\left(\mathrm{CH}_{4}\right)$, and hydrogen $\left(\mathrm{H}_{2}\right)$ yields obtained by calcining the catalyst at two different temperatures were not very different. However, the carbon dioxide $\left(\mathrm{CO}_{2}\right)$ yield 
produced by the catalyst calcined at $1100{ }^{\circ} \mathrm{C}$ was higher than that of the catalyst calcined at $900{ }^{\circ} \mathrm{C}$ (Zhang et al. 2014). This was because in the catalytic pyrolysis of straw, a lot of tar was produced ( $\mathrm{Yu}$ et al. 2009). Tar causes corrosion and blockage of the equipment pipeline, and the produced $\mathrm{CO}_{2}$ has a good effect on the catalytic cracking of the catalyst tar (Rezaei et al. 2014).

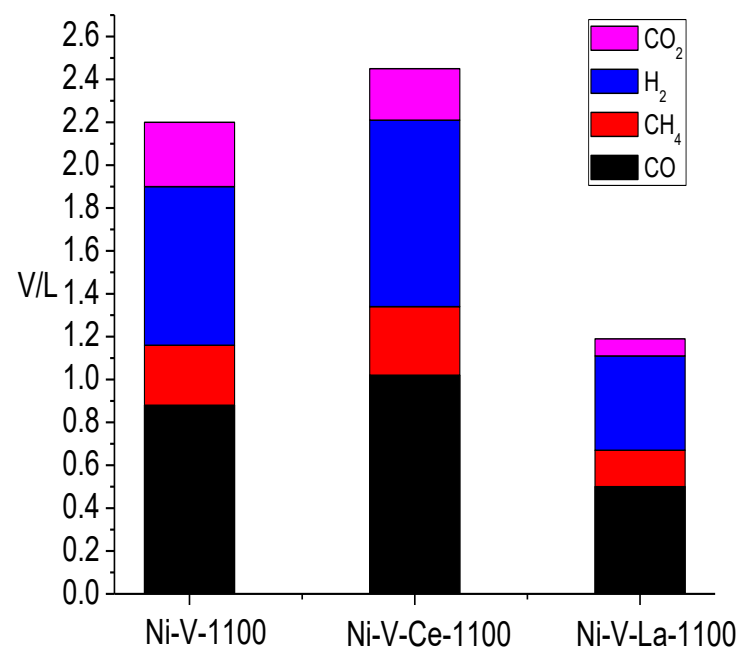

Fig. 6. Influence of calcination at $1100^{\circ} \mathrm{C}$ with a pyrolysis temperature of $800^{\circ} \mathrm{C}$

\section{Effect of the pyrolysis temperature}

With an increase in the pyrolysis temperature, the $\mathrm{CO}, \mathrm{CH}_{4}, \mathrm{H}_{2}$, and $\mathrm{CO}_{2}$ contents increased (Horne and Williams 1996). The pyrolysis temperature greatly affected the catalytic performance of the catalyst, which could promote the syngas yield with an increase in the temperature. Higher pyrolysis temperatures are more likely to promote the cracking of tar (Pütün 2010). The cracking of tar promoted the production of $\mathrm{H}_{2}, \mathrm{CH}_{4}$, and $\mathrm{CO}$ (Yu et al. 1997). From the above results, the production of syngas at $800{ }^{\circ} \mathrm{C}$ was higher than that at $600{ }^{\circ} \mathrm{C}$. This was because at the high pyrolysis temperature, the catalytic activity of the catalyst was promoted, which made the $\mathrm{C}-\mathrm{H}$ bonds easier to break and caused an increase in the syngas content (Yang et al. 2010). Meanwhile, the deposited carbon reacted with $\mathrm{CO}_{2}$, which caused a relatively high $\mathrm{CO}$ content and low $\mathrm{CO}_{2}$ content (Yang et al. 2010).

\section{CCHP System}

The CCHP system was conceptualized as two modules. One module was biomass pyrolysis gas production, and the other module was the use of syngas (Wang et al. 2015a). In the first module, the gas data obtained from the pyrolysis experiments was used, and the resulting gas data was used in the Aspen Plus software for simulation. In the simulation process, the calorific value produced by the combustion of syngas and oxygen was obtained. The simulated calorific values are shown in Table 1.

\section{Calorific Value Analysis}

From Table 1, the highest calorific value was $251.4 \mathrm{~J} / \mathrm{s}$. Because the Ni/V-Ce catalyst was added during this pyrolysis process, it was calcined at $1100{ }^{\circ} \mathrm{C}$. Ion-exchange metallic-nickel and cerium nanoparticles were oxidized after calcination, which has been 
found to be an effective catalyst composition for the catalytic cracking of biomass. The pyrolysis process was performed at $800{ }^{\circ} \mathrm{C}$, which is a high pyrolysis temperature. The catalytic activity of the catalyst was promoted, which made the $\mathrm{C}-\mathrm{H}$ bonds easier to break and caused an increase in the $\mathrm{H}_{2}$ content. Meanwhile, the deposited carbon reacted with $\mathrm{CO}_{2}$, which caused a relatively high $\mathrm{CO}$ content and low $\mathrm{CO}_{2}$ content.

Table 1. Calorific Value of the Syngas

\begin{tabular}{ccc}
\hline \multirow{2}{*}{ Catalysts } & \multicolumn{2}{c}{ Calorific Value } \\
& Cal/s & $\mathrm{J} / \mathrm{s}$ \\
\hline NC-600 & 17.85 & 74.73 \\
$900-\mathrm{NI}-\mathrm{V}-600$ & 39.41 & 164.95 \\
$900-\mathrm{NI}-\mathrm{V}-\mathrm{Ce}-600$ & 42.98 & 179.90 \\
$900-\mathrm{V}-$ La-600 & 44.89 & 187.91 \\
NC-800 & 39.66 & 166.02 \\
$900-\mathrm{NI}-\mathrm{V}-800$ & 39.88 & 166.94 \\
$900-\mathrm{NI}-\mathrm{V}-\mathrm{Ce}-800$ & 47.95 & 200.72 \\
$900-\mathrm{NI}-\mathrm{V}-\mathrm{La}-800$ & 53.56 & 224.21 \\
$1100-\mathrm{NI}-\mathrm{V}-600$ & 39.41 & 164.95 \\
$1100-\mathrm{NI}-\mathrm{V}-\mathrm{Ce}-600$ & 42.08 & 176.16 \\
$1100-\mathrm{NI}-\mathrm{V}-\mathrm{La}-600$ & 45.27 & 189.51 \\
$1100-\mathrm{NI}-\mathrm{V}-800$ & 56.13 & 234.96 \\
$1100-\mathrm{NI}-\mathrm{V}-\mathrm{Ce}-800$ & 60.07 & 251.43 \\
$1100-\mathrm{NI}-\mathrm{V}-\mathrm{L}-800$ & 46.04 & 192.71 \\
\hline
\end{tabular}

\section{Equipment Parameter Analysis}

Process parameters of the TFRJ3K straw gas engine

The process parameters of the TFRJ3K straw gas engine purchased from Taifa Company (Zhejiang Taifa Mechnical \& Electrical Industry Co. Ltd., Taizhou, Zhejiang, China) are given in Table 2.

Table 2. Process Parameters of the TFRJ3K Straw Gas Engine

\begin{tabular}{|c|c|c|c|}
\hline Model & T420 & Maximum Output Power & \\
\hline Type & Forced Air Cooling & Size L $\times \mathrm{W} \times \mathrm{H} \mathrm{mm}$ & $700 \times 525 \times 580$ \\
\hline Spinning Speed & $800 \mathrm{rpm}$ & Weight $(\mathrm{kg})$ & 95 \\
\hline Fuel & Straw Gas & Ignition System & Transistor Ignition \\
\hline Gas Consumption & $3.76 \mathrm{Nm}^{3} / \mathrm{kWh}$ & Start System & Electric Start \\
\hline $\begin{array}{c}\mathrm{H}_{2} \text { Minimum } \\
\text { Score }\end{array}$ & $14 \%$ & $\begin{array}{c}\text { Exhaust Gas } \\
\text { Temperature }\end{array}$ & $450^{\circ} \mathrm{C}$ \\
\hline $\begin{array}{c}\text { Minimum Calorific } \\
\text { Value of Gas }\end{array}$ & $4 \mathrm{MJ} / \mathrm{Nm}^{3}$ & Thermal Efficiency & $26.5 \%$ \\
\hline
\end{tabular}

TFRJ3K straw gas power generation process parameters

The parameters for power generation in the TFRJ3K straw gas engine are given in Table 3. 
Table 3. TFRJ3K Straw Gas Power Generation Process Parameters

\begin{tabular}{|c|c|c|c|}
\hline Model & TFBG3GF & Piston Movement Volume & $3.2 \mathrm{~L}$ \\
\hline Type & Brushed 3 phase & Compression Ratio & 9.0 \\
\hline Rated Power & $3 \mathrm{~kW}$ & Test Maximum Power & $3.1 \mathrm{~kW}$ \\
\hline $\begin{array}{c}\text { Maximum Output } \\
\text { Power }\end{array}$ & $3.3 \mathrm{~kW}$ & Voltage Regulation & $\begin{array}{c}\text { Automatic Voltage } \\
\text { Regulation }\end{array}$ \\
\hline
\end{tabular}

From Tables 2 and 3 , the $\mathrm{H}_{2}$ content in the syngas in the pyrolysis experiment was greater than $14 \%$. Therefore, the experimental results can meet the requirements of the power generation equipment. The output of $220 \mathrm{~V}$ (in China) reaches the standard of household appliances, and the rated power of power generation is $3 \mathrm{~kW}$, which also can meet the requirements of general household appliances. So the equipment can be applied to CCHP mode under the condition that the experimental results are met. The heat value generated by inputting $2 \mathrm{~g}$ of straw was $251.43 \mathrm{~J} / \mathrm{s}$; when $31.82 \mathrm{~kg}$ of straw were added, the calorific value generated was greater than $4 \mathrm{MJ} / \mathrm{Nm}^{3}$. Therefore, the gas output conditions met the parameters required by the generator equipment.

Cost Analysis of the Cooling, Heating, and Power System

Schematic diagram of the cost analysis of the cooling, heating, and power system

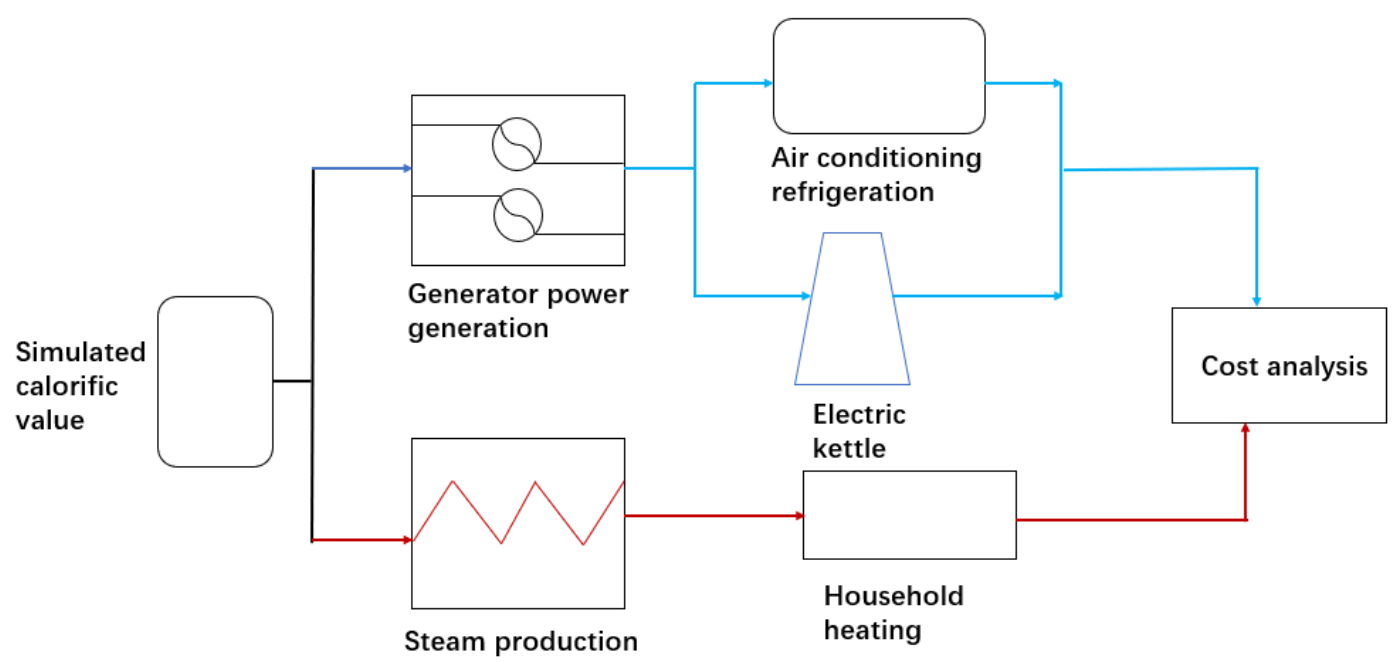

Fig. 7. Schematic diagram for the cost analysis of the cooling, heating, and power

From Fig. 7, the simulated calorific value was used to generate electricity and generate hot steam, the electricity generated was used for air conditioner cooling, and the electric kettle was used to boil hot water. The calorific value generated by straw, which was dried in the natural conditions for a week to remove natural moisture, was used to heat the boiler. The hot steam generated by the boiler was passed to the heating device in the home to perform heating in the winter. Based on the above analysis, the cost of coal-fired power generation can be compared.

For straw syngas power generation (Table 2), $1 \mathrm{~g}$ of straw has a calorific value of 125.7 $\mathrm{J}$ under the condition of satisfying the minimum calorific value of the TFRJ3K straw syngas generator. Because $3.6^{*} 10^{6} \mathrm{~J}=1 \mathrm{~kW}^{*} \mathrm{~h}, 3.6^{*} 10^{6} \mathrm{~J} * 26.5 \% / 125.715 \mathrm{~J}=7588 \mathrm{~g}$. It 
follows that approximately $32 \mathrm{~kg}$ of straw were needed, which can generate $3 \mathrm{~kW}$ of electricity. The market price of the straw was approximately $120 \mathrm{RMB} / \mathrm{ton}$. Calculated in this way, the cost of producing the straw needed for $1.0 \mathrm{~kW} \cdot \mathrm{h}$ of electricity was 0.12 $\mathrm{kg} / \mathrm{RMB}$. In other words, the economic electricity cost was $1.2 \mathrm{RMB}$. For example, an electric kettle has a power of approximately $1500 \mathrm{~W}$ and a pot of water can be boiled in approximately $10 \mathrm{~min}$, which means it takes approximately $0.3 \mathrm{~kW}$ to boil a pot of water. Therefore, the economic cost of boiling a pot of water was 0.36 RMB. Another example was a $790 \mathrm{~W}$ air conditioner with a cooling temperature of $26^{\circ} \mathrm{C}$; if the air conditioner was used continuously for $24 \mathrm{~h}$, it used $18.96 \mathrm{~kW}$ of electricity. Its economic cost was therefore 22.752 RMB.

For household heating, radiator heat can be simplified into a heat exchanger model for calculation. It was assumed in this study that the inlet temperature of the hot steam was $120^{\circ} \mathrm{C}$, the room temperature in the winter house was $10^{\circ} \mathrm{C}$, which was heated to $26^{\circ} \mathrm{C}$, and the heat exchange area was $3.14 \mathrm{~m}^{2}$. The flow rate of the hot steam was $1.2 \mathrm{~m} / \mathrm{s}$. The equation for heating is as follows:

$$
Q=W_{\mathrm{h}} C_{\mathrm{p}, \mathrm{h}}\left(T_{1}-T_{2}\right)=W_{\mathrm{c}} C_{\mathrm{p}, \mathrm{c}}\left(t_{2}-t_{1}\right)
$$

where $Q$ is the heat load of the heat exchanger $(\mathrm{kW}), W_{\mathrm{h}}$ is the condensation rate of the saturated steam $(\mathrm{kg} / \mathrm{h}), C_{\mathrm{p}, \mathrm{h}}$ is the average constant pressure specific heat capacity of the fluid $\left(\mathrm{kJ} /\left(\mathrm{kg} \cdot{ }^{\circ} \mathrm{C}\right)\right), T_{1}$ is the hot steam inlet temperature $\left({ }^{\circ} \mathrm{C}\right), T_{2}$ is the hot steam outlet temperature $\left({ }^{\circ} \mathrm{C}\right), t_{2}$ is the room temperature after heating $\left({ }^{\circ} \mathrm{C}\right)$, and $t_{1}$ is the room temperature before heating $\left({ }^{\circ} \mathrm{C}\right)$.

From the above equation and using a $T_{2}$ of $107^{\circ} \mathrm{C}, 60 \mathrm{~kg}$ of hot steam met the above conditions, provided that $60 \mathrm{~kg}$ of steam heat value requires $16.7 \mathrm{~kg}$ of biomass. Its economic value was $20 \mathrm{RMB}$.

\section{CONCLUSIONS}

1. After adding the catalyst, the content of syngas was significantly increased.

2. A simplified model of the simulated calorific value of biomass derived syngas was constructed. The biomass syngas yield produced from the experiments was close to the actual situation.

3. The calorific value simulated by the syngas was then used to calculate the cost of cooling, heating, and power by a household user.

4. In addition, the cost for different electricity usage methods was obtained. This provided a new way of thinking for the establishment of a future cooling, heating, and power model.

\section{ACKNOWLEDGEMENTS}

The authors are grateful for the financial support provided by the Technological Innovation Major Project of Hubei Province (Grant No. 2017ABA155) and the Public Welfare Industry (agriculture) Research special project (Grant No. 2015030135). 


\section{REFERENCES CITED}

Atong, D., Pechyen, C., Aht-Ong, D., and Sricharoenchaikul, V. (2011). "Synthetic olivine supported nickel catalysts for gasification of glycerol," Appl. Clay Sci. 53(2), 244-253. DOI: 10.1016/j.clay.2011.01.030

Cheah, S., Gaston, K. R., Parent, Y. O., Jarvis, M. W., Vinzant, T. B., Smith, K. M., Thornburg, N. E., Nimlos, M. R., and Magrini-Bair, K. A. (2013). "Nickel cerium olivine catalyst for catalytic gasification of biomass," Appl. Catal. B-Environ. 134135, 34-45. DOI: 10.1016/j.apcatb.2012.12.022

Horne, P. A., and Williams, P. T. (1996). "Influence of temperature on the products from the flash pyrolysis of biomass," Fuel 75(9), 1051-1059. DOI: 10.1016/00162361(96)00081-6

James, A. M., Yuan, W., Boyette, M. D., Wang, D., and Kumar, A. (2014). 'In-chamber thermocatalytic tar cracking and syngas reforming using char-supported $\mathrm{NiO}$ catalyst in an updraft biomass gasifier," Int. J. Agr. Biol. Eng. 7(6), 91-97.

DOI: 10.3965/j.ijabe.20140706.011

Maraver, D., Sin, A., Sebastián, F., and Royo, J. (2013). "Environmental assessment of CCHP (combined cooling heating and power) systems based on biomass combustion in comparison to conventional generation," Energy 57, 17-23.

DOI: $10.1016 /$ j.energy.2013.02.014

Mazumder, J., and de Lasa, H. I. (2015). "Fluidizable $\mathrm{La}_{2} \mathrm{O}_{3}$ promoted $\mathrm{Ni} / \gamma-\mathrm{Al}_{2} \mathrm{O}_{3}$ catalyst for steam gasification of biomass: Effect of catalyst preparation conditions," Appl. Catal. B-Environ. 168-169, 250-265. DOI: 10.1016/j.apcatb.2014.12.009

Mertzis, D., Mitsakis, P., Tsiakmakis, S., Manara, P., Zabaniotou, A., and Samaras, Z. (2014). "Performance analysis of a small-scale combined heat and power system using agricultural biomass residues: The SMARt-CHP demonstration project," Energy 64, 367-374. DOI: 10.1016/j.energy.2013.11.055

Mokhnachuk, O. V., Soloviev, S. O., and Kapran, A. Y. (2007). "Effect of rare-earth element oxides $\left(\mathrm{La}_{2} \mathrm{O}_{3}, \mathrm{Ce}_{2} \mathrm{O}_{3}\right)$ on the structural and physico-chemical characteristics of $\mathrm{Pd} / \mathrm{Al}_{2} \mathrm{O}_{3}$ monolithic catalysts of nitrogen oxide reduction by methane," Catal. Today 119(1-4), 145-151. DOI: 10.1016/j.cattod.2006.08.061

Pütün, E. (2010). "Catalytic pyrolysis of biomass: Effects of pyrolysis temperature, sweeping gas flow rate and MgO catalyst," Energy 35(7), 2761-2766.

DOI: $10.1016 /$ j.energy.2010.02.024

Quan, C., Gao, N., and Wu, C. (2018). "Utilization of NiO/porous ceramic monolithic catalyst for upgrading biomass fuel gas," J. Energy Inst. 91(3), 331-338.

DOI: 10.1016/j.joei.2017.02.008

Remiro, A., Valle, B., Aguayo, A. T., Bilbao, J., and Gayubo, A. G. (2013). “Operating conditions for attenuating $\mathrm{Ni} / \mathrm{La}_{2} \mathrm{O}_{3}-\alpha \mathrm{Al}_{2} \mathrm{O}_{3}$ catalyst deactivation in the steam reforming of bio-oil aqueous fraction," Fuel Process. Technol. 115, 222-232. DOI: 10.1016/j.fuproc.2013.06.003

Rezaei, P. S., Shafaghat, H., and Wan Daud, W. M. A. (2014). "Production of green aromatics and olefins by catalytic cracking of oxygenate compounds derived from biomass pyrolysis: A review," Appl. Catal. A-Gen. 469, 490-511.

DOI: 10.1016/j.apcata.2013.09.036

Shi, X.-w., Xin, X., Liu, Z., Lu, Y., Li, H.-X., Li, J.-f., and Chen, Q.-p. (2018). "Preparation and characterization of Ni/TPC catalyst and applied in straw pyrolysis gas reforming," J. Fuel Chem.Technol. 46(6), 659-665. 
DOI: $10.1016 / \mathrm{S} 1872-5813(18) 30028-8$

Valle, B., Remiro, A., Aguayo, A. T., Bilbao, J., and Gayubo, A. G. (2013). "Catalysts of $\mathrm{Ni} / \alpha-\mathrm{Al}_{2} \mathrm{O}_{3}$ and $\mathrm{Ni} / \mathrm{La}_{2} \mathrm{O}_{3}-\alpha \mathrm{Al}_{2} \mathrm{O}_{3}$ for hydrogen production by steam reforming of biooil aqueous fraction with pyrolytic lignin retention," Int. J. Hydrogen Energ. 38(3), 1307-1318. DOI: 10.1016/j.ijhydene.2012.11.014

Wang, H., Yan, J., and Dong, L. (2016). "Simulation and economic evaluation of biomass gasification with sets for heating, cooling and power production," Renew. Energ. 99, 360-368. DOI: 10.1016/j.renene.2016.07.001

Wang, J., Mao, T., Sui, J., and Jin, H. (2015a). "Modeling and performance analysis of CCHP (combined cooling, heating and power) system based on co-firing of natural gas and biomass gasification gas," Energy 93(Part 1), 801-815.

DOI: 10.1016/j.energy.2015.09.091

Wang, J.-J., Yang, K., Xu, Z.-L., Fu, C., Li, L., and Zhou, Z.-K. (2014). “Combined methodology of optimization and life cycle inventory for a biomass gasification based BCHP system," Biomass Bioenerg. 67, 32-45. DOI: 10.1016/j.biombioe.2014.03.026

Wang, J.-J., Yang, K., Xu, X.-L., and Fu, C. (2015b). "Energy and exergy analyses of an integrated CCHP system with biomass air gasification," Appl. Energ. 142, 317-327. DOI: 10.1016/j.apenergy.2014.12.085

Yang, X., Xu, S., Xu, H., Liu, X., and Liu, C. (2010). "Nickel supported on modified olivine catalysts for steam reforming of biomass gasification tar," Catal. Commun. 11(5), 383-386. DOI: 10.1016/j.catcom.2009.11.006

Yu, Q., Brage, C., Chen, G., and Sjöström, K. (1997). "Temperature impact on the formation of tar from biomass pyrolysis in a free-fall reactor," J. Anal. Appl. Pyrol. 40-41, 481-489. DOI: 10.1016/S0165-2370(97)00017-X

Yu, Q.-Z., Brage, C., Nordgreen, T., and Sjöström, K. (2009). "Effects of Chinese dolomites on tar cracking in gasification of birch," Fuel 88(10), 1922-1926. DOI: 10.1016/j.fuel.2009.04.020

Zhang, R., Wang, H., and Hou, X. (2014). "Catalytic reforming of toluene as tar model compound: Effect of Ce and Ce-Mg promoter using Ni/olivine catalyst," Chemosphere 97, 40-46. DOI: 10.1016/j.chemosphere.2013.10.087

Article submitted: December 22, 2018; Peer review completed: April 20, 2019; Revised version received: May 3, 2019; Accepted; May 6, 2019; Published: May 13, 2019. DOI: 10.15376/biores.14.3.5224-5234 